\title{
Influences of organic manure addition on the maturity and quality of pineapple fruits ripened in winter
}

\author{
C.H. Liu* and Y. Liu \\ Institute of Fruit Tree Research, Guangdong Academy of Agricultural Sciences, 510640, Guangzhou, P. R. China. \\ Key laboratory and south subtropical fruit biology and genetic resource utilization, Ministry of Agriculture, $P$. \\ R. China. ${ }^{*}$ Corresponding author: founderlch@126.com
}

\begin{abstract}
A field experiment was conducted to investigate the influence of the addition of organic manure on the maturity stage and quality of pineapple fruits ripened in winter. Fertilization was performed with $200 \mathrm{~mL}$ peanut-press pulp liquid fertilizer $+20 \mathrm{~g}$ compound fertilizer per plant (T1) or $100 \mathrm{~mL}$ peanut press pulp liquid fertilizer + $20 \mathrm{~g}$ compound fertilizer per plant (T2). Fertilization with $20 \mathrm{~g}$ compound fertilizer per plant (T0) was used as the control. The results indicated that organic fertilizer addition promoted maturity. The weight per fruit was increased, and the contents of TSS and total sugars were enhanced, whereas the titratable acid contents were decreased. A sensory evaluation indicated that, after the addition of organic manure, the pineapple fruits were sweeter and more fragrant. More types of ester aroma components having a higher total relative content were identified in T1, and more types of alkenes having a higher total relative content were identified in T2. The relative contents of propanoic acid, 3-(methylthio)-, and methyl ester were increased by organic manure treatments, with the highest being noted in T1 $(5.79 \%)$, followed by $\mathrm{T} 2(5.59 \%)$, and the lowest was documented in T0 (4.36\%).
\end{abstract}

Keywords: pineapple, fruits ripened in winter, organic manure, maturity stage, quality 


\section{Introduction}

Pineapple [Ananas comosus (L.) Merr.], an important representative of the Bromeliaceae family, is widely cultivated throughout tropical and subtropical regions. Pineapple fruits are consumed freshly as table fruit or in desserts and are an important source of essential mineral elements, nutrients and vitamins.

With the use of ethephon for flower induction, pineapple plants can now be fruited and harvested multiple times year round. Because of the different climates throughout the year, however, the pineapple fruits ripened during different seasons are diverse in both quality and fragrance (Liu et al., 2011a), with the fruits ripened in summer being the sweetest and best in fragrance. In contrast, the fruits ripened in cool and cold seasons, such as autumn and winter, are acidic and relatively poor in fragrance. Therefore, farmers face the problem of improving the quality of pineapple fruits ripened during such cool and cold seasons.

Many factors influence fruit quality, and one of the main factors is the fertilization system. The quality and quantity of applied fertilizers are key factors affecting the growth, yield, and quality of crops (Chang et al., 2010). However, the continuous use of chemical fertilization leads to the deterioration of soil characteristics and fertility and might lead to the accumulation of heavy metals in plant tissues, affecting the fruit nutritional value and edibility (Shimbo et al., 2001). The application of organic fertilizers, which are made from animal excreta or other agricultural wastes, contributes to the sustainability of agriculture systems and is usually used to improve the soil structure and stability in addition to enhancing the yield and, in particular, the quality of plants (Tejada and Gonzalez, 2003; Abou El- Magd et al., 2006; Chang et al., 2010; Marzouk and Kassem, 2011).

The growing attention of consumers with regard to food safety and environmental concerns has contrib- uted to the expansion of the organic farming system in recent years (Chang et al., 2007; Zaccone et al., 2010). A major benefit of organic agriculture, and an assumption by consumers of organic products, is the increased nutritional properties of these products as along with food safety and the reduction of harmful effects on the environment (Bourn and Prescott, 2002). The main improvement of fruit quality is demonstrated by a decrease in the nitrate salt content and improvements in the fruit flavor, sweetness and stable Vc content ( $\mathrm{Li}$ et al., 2009). Thus, consumers often regard organically produced food to be tastier and healthier than conventional products (Ekelund and Tjärnemo, 2004).

However, there is little information about the utilization of organic fertilizer in growing pineapple and even less data on the addition of organic manure to improve the quality of pineapple fruits ripened in cool and cold seasons. This present study was conducted to assess the effects of the addition of organic fertilizer on the maturity stage, individual weight and chemical quality of pineapple fruits ripened during the winter. Additionally, we documented the results of the aroma components of pineapple fruits, as influenced by the addition of organic fertilizer.

\section{Materials and Methods}

\subsection{Site description}

A field experiment was conducted at an experimental orchard at the Institute of Fruit Tree Research, Guangdong Academy of Agricultural Sciences, Tianhe District (113.35N, 23.12E), Guangzhou, Guangdong Province, P. R. China. The local climate is characterized by a southern subtropical monsoon climate, with a mean annual precipitation of over $1800 \mathrm{~mm}$ and an average annual air temperature of $21.5^{\circ} \mathrm{C}$ to $22.2^{\circ} \mathrm{C}$. 
The monthly average temperature reaches a high between Jun. and Aug., at approximately $28 \sim 35^{\circ} \mathrm{C}$, and the low monthly average is documented occurs from Nov. to Feb., at approximately $10 \sim 15^{\circ} \mathrm{C}$. The soil type of the experimental area was a sandy loam soil of $\mathrm{pH} 6.5$, with $76.83 \mathrm{mg} / \mathrm{kg}$ available $\mathrm{N}, 178.81 \mathrm{mg} / \mathrm{kg}$ available $\mathrm{P}$, and $233.84 \mathrm{mg} / \mathrm{kg}$ available $\mathrm{K}$.

\subsection{Plant material and treatments}

The pineapple cultivar 'Yueyinaoka', categorized as Cayenne, was used as the material in this study. At approximately $25 \mathrm{~cm}$ in height, tissue-cultured seedlings were transplanted to the experimental field in June of 2009. The plant to plant distance within the rows and between the rows was 30 and $40 \mathrm{~cm}$, respectively. The plants were forced to flower with $40 \%$ ethephon (5 $\left.\mathrm{mL} \cdot \mathrm{L}^{-1}\right)$ in late June of 2010 , when they were approximately $100 \mathrm{~cm}$ in height.

The fertilizer experiment was conducted in late August 2010 when the flowers were fading. The field experiment was arranged as a random block design, with three repetitions and three treatments. In this experiment, the pineapple plants were fertilized with $200 \mathrm{~mL}$ peanut-press pulp liquid fertilizer $+20 \mathrm{~g}$ compound fertilizer per plant (T1) or $100 \mathrm{~mL}$ peanut-press pulp liquid fertilizer $+20 \mathrm{~g}$ compound fertilizer per plant (T2); plants fertilized with only $20 \mathrm{~g}$ compound fertilizer per plant (T0) were used as the control. The peanut-press pulp liquid fertilizer was fermented and well composted from dried peanut-press pulp, with a twofold weight of water. In terms of the composition, the dried peanut-press pulp contained $71.76 \%$ organic matter, $6.96 \%$ total $\mathrm{N}, 1.78 \% \mathrm{P}_{2} \mathrm{O}_{5}$, and $1.57 \% \mathrm{~K}_{2} \mathrm{O}$; the compound fertilizer contained $15 \% \mathrm{~N}, 15 \% \mathrm{P}_{2} \mathrm{O}_{5}$, and $15 \% \mathrm{~K}_{2} \mathrm{O}$. Every block was approximately $1.0 \mathrm{~m}$ in width and $8 \mathrm{~m}$ in length. All of the plants were fertilized every fifteen days from the start of experimental treatments to the harvest. Three fruits with same maturation degree were randomly harvested from every block for the quality detection in mid-November of 2010 .

\subsection{Measurements of physical and chemical Indices}

For the harvested fruits, we determined the following physical and chemical quality parameters: the weight per fruit, TSS content, total sugar content, sucrose content, titratable acid content, vitamin $\mathrm{C}$ content, sugar/acid ratio and a sensory evaluation.

The weight per fruit was measured using an electronic balance, and the determination of the total soluble solids (TSS) was conducted by measuring the soluble solids directly using a hand refractometer scale. The total sugar content was determined according to GB/T 6194-1986, and the sucrose content was determined based on GB/T 5009.8-2008. The determination of the titratable acidity (percentage of citric acid) was based on a titration with a solution of sodium hydroxide according to GB/T 12293-1990. The ratio between the total sugar and titratable acid was calculated by dividing the content of total sugar by the content of titratable acid. The determination of vitamin $\mathrm{C}$ was conducted using the titrimetric method with 2,6-dichlorphenolindophenol according to GB/T 6195-1986. The sensory evaluation was performed by three people, with the fruits receiving more ' + ' scores being judged better in taste and fragrance.

\subsection{Aroma component identification}

The aroma components were analyzed by SPME/ GC-MS according to Liu et al. (2009a). The MS was operated using an EI ion source, with a temperature of $170{ }^{\circ} \mathrm{C}$, electron energy $70 \mathrm{eV}$, and photomultiplier tube voltage of $350 \mathrm{~V}$. The mass-scanning range was 35 335 amu. The aroma components were ten- 
tatively identified by comparing their mass spectra with the mass spectra of the NIST library, and the relative content of each component was determined by their peak area.

\subsection{Statistical analysis}

The data of the weight per fruit and chemical quality were tested for statistical significance using the analysis of variance package included in Microsoft Excel 2003 and SPSS Statistics 17.0. Mean comparisons were performed using Duncan's multiple range tests. A probability level of $P \leq 0.05$ was considered significant.

\section{Results and Discussion}

\subsection{Maturity stage, physical and chemical characteristics}

The results with regard to the maturity and quality of the pineapple fruits are presented in Table 1. After the treatment in June of 2010, the pineapple fruits under the $\mathrm{T} 1$ treatment matured between 8 and 22 November, and the fruits of $\mathrm{T} 2$ matured from 13 to 23 November 2010; the fruits of T0 matured from 13 to 27 November. Thus, the fruits under the $\mathrm{T} 1$ and $\mathrm{T} 2$ treatments ripened earlier than T0 by 2 7 days; a similar result was obtained by Shao and Huang (2010) working on tomato. In our study, the individual weights of the fruits for T1, T2 and T0 were $1598.5 \mathrm{~g}, 1384.2 \mathrm{~g}$ and 1167.7 $\mathrm{g}$, respectively, and a statistical analysis showed that the $\mathrm{T} 1$ weight per fruit was significantly higher than $\mathrm{T} 0$ $(p<0.05)$. Therefore, the weight per fruit was increased by the addition of organic manure, which was in accord with previous studies (Shi et al., 2004; Ye et al., 2004; Tang et al., 2008; Li et al., 2009).

Regarding the fruit chemical characteristics, the data of the two treatments and control presented in Table 1 indicate significant effects on the fruit chemi- cal quality after the addition of the organic fertilizer. The TSS under the T1, T2 and T0 treatments were $19.0 \%, 17.2 \%$ and $14.5 \%$, respectively, and a statistical analysis showed that there were significant differences among T1, T2 and T0 $(p<0.05)$. The contents of total sugar increased for T1 (16.47\%) and T2 (12.09\%), compared with T0 (10.76\%); in particular, a significant difference was observed between $\mathrm{T} 1$ and T0 $(p<0.05)$. The highest content of sucrose was obtained under the T1 $(8.78 \%)$ treatment, followed by T2 (7.64\%) and T0 (6.21\%); however, the differences among the two treatments and control were not statistically significant $(p>0.05)$. The highest value of titratable acid was noted in the fruits under the T0 treatment, $1.01 \%$, which was followed by $\mathrm{T} 2$ at $0.95 \%$. The lowest amount of titratable acid was noted under the $\mathrm{T} 1$ treatment, $0.67 \%$, and a significant difference was observed for $\mathrm{T} 1$ when compared with $\mathrm{T} 2$ and $\mathrm{T} 0$ $(p<0.05)$. The ratio between the total sugar and titratable acid of the pineapple fruits was increased by the addition of organic manure. In contrast, the quantity of vitamin $\mathrm{C}$ was somewhat unfavorable under the two treatments, with the highest value of vitamin $\mathrm{C}$ in the T0 fruits, at $15.0 \mathrm{mg} / 100 \mathrm{~g}$, whereas the vitamin C value for $\mathrm{T} 1$ was the lowest, at $12.8 \mathrm{mg} / 100 \mathrm{~g}$.

The above results indicated an enhancement in the fruit chemical quality characteristics, especially for the TSS, total sugars, ratio of total sugar and titratable acid with the addition of organic manure. The sensory evaluation also indicated that the pineapple fruits treated with organic manure were better in fragrance and sensory than the control. It was one reason why the fruits of T1 and T2 were better in fragrance and sensory than that of control in this research. Similar findings were reported by Shi et al. (2004) studying tomato and Lai et al. (2005) studying strawberries. In addition, Lu et al. (2003) reported that the application of organic manure enhanced the quality of apple fruits by improving the peel color and increasing the firmness and TSS content. 
Table 1. Effects of organic fertilizer addition on the maturation and quality of pineapple fruits

\begin{tabular}{|c|c|c|c|c|c|c|c|c|c|}
\hline $\begin{array}{l}\text { Treat- } \\
\text { ments }\end{array}$ & $\begin{array}{l}\text { Maturity } \\
\text { stage* }\end{array}$ & $\begin{array}{l}\text { Weight per } \\
\text { fruit (g) }\end{array}$ & TSS (\%) & $\begin{array}{c}\text { Total sugar } \\
(\%)\end{array}$ & $\begin{array}{c}\text { Sucrose } \\
(\%)\end{array}$ & $\begin{array}{l}\text { Titrat- } \\
\text { able acid } \\
\quad(\%)\end{array}$ & $\begin{array}{c}\text { Total } \\
\text { sugar / } \\
\text { Titrata- } \\
\text { ble acid }\end{array}$ & $\begin{array}{c}\text { Vitamin C } \\
(\mathrm{mg} \cdot 100 \\
\left.\mathrm{g}^{-1}\right)\end{array}$ & $\begin{array}{c}\text { Sensory } \\
\text { evalua- } \\
\text { tion }\end{array}$ \\
\hline $\mathrm{T} 1$ & $11.8 \sim 11.22$ & $1598.5 \pm 140.1 \mathrm{a}$ & $19.0 \pm 0.4 \mathrm{a}$ & $16.47 \pm 0.35 \mathrm{a}$ & $8.78 \pm 0.99 \mathrm{a}$ & $0.67 \pm 0.04 b$ & $24.7 \pm 1.7 \mathrm{a}$ & $12.8 \pm 0.7 \mathrm{~b}$ & +++ \\
\hline $\mathrm{T} 2$ & $11.13 \sim 11.23$ & $1384.2 \pm 46.3 \mathrm{ab}$ & $17.2 \pm 0.2 \mathrm{~b}$ & $12.09 \pm 3.83 \mathrm{ab}$ & $7.64 \pm 2.51 \mathrm{a}$ & $0.95 \pm 0.03 \mathrm{a}$ & $\begin{array}{c}12.6 \pm 3.8 \\
b\end{array}$ & $16.8 \pm 0.7 \mathrm{a}$ & ++ \\
\hline T0 & $11.13 \sim 11.27$ & $1167.7 \pm 22.8 \mathrm{~b}$ & $14.5 \pm 0.7 \mathrm{c}$ & $10.76 \pm 1.61 \mathrm{~b}$ & $6.21 \pm 0.26 \mathrm{a}$ & $1.01 \pm 0.0 .1 \mathrm{a}$ & $\begin{array}{c}10.7 \pm 1.6 \\
\mathrm{~b}\end{array}$ & $15.0 \pm 0.3 \mathrm{a}$ & + \\
\hline
\end{tabular}

Note: *the maturity stage was indicated as month. date

Values within a column with the same letter(s) are not significantly different by Duncan's test $(P=0.05)$

\subsection{Aroma components}

The GC-MS total ionic chromatograms of the aroma components of the fruits under the two treatments and control are presented in Fig. 1. The aroma components were identified by searching NIST, and the relative contents were determined based on the peak area.

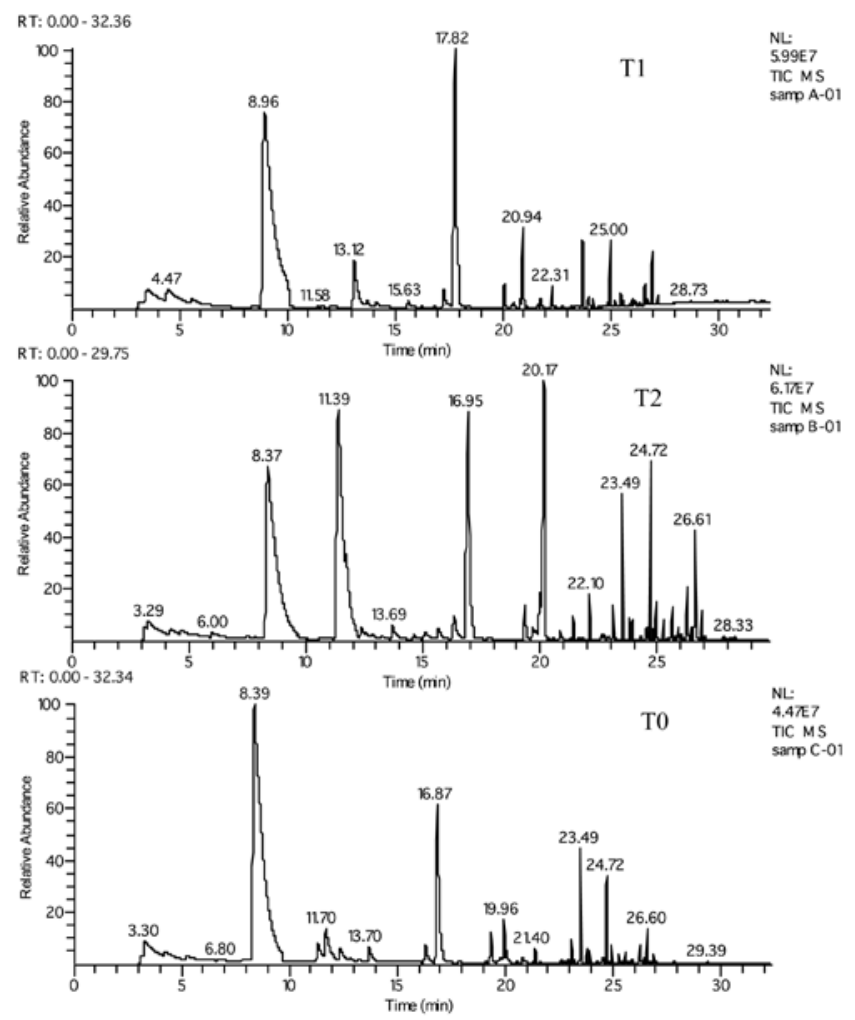

Figure 1. Total GC-MS ionic chromatogram of the aroma components of pineapple fruits of the treatments and control 
A desirable, rich, fruity aroma typical of the fruit is often used by the consumer as an indicator of quality, ripeness, and freshness. Therefore, the volatile composition of the fruit provides the consumer with a good indicator of quality and is frequently used in making a purchasing decision.

In this study, there were 31 types of aroma components detected in the pineapple fruits. In addition to one type of alcohol identified in the fruits of T1, esters and alkenes were the main aroma components of all of the pineapple fruits (Table 2). This result confirmed previous reports that aroma components of pineapple fruits were predominated by esters and alkenes (Preston et al., 2003; Elss et al., 2005; Liu et al., 2011b).

However, the aroma components and their relative contents under the two treatments and control were diverse. In total, 19 types of aroma components were identified in the fruits of T1, including 12 esters, 1 alcohol and 6 alkenes, with total relative content of $94.45 \%, 0.09 \%$ and $5.45 \%$, respectively. For the 12 types of esters, the predominant were hexanoic acid, methyl ester, octanoic acid, methyl ester, and propanoic acid, 3-(methylthio), -methyl ester, with relative contents of $55.14 \%, 25.85 \%$ and $5.79 \%$, respectively. For the 6 types of alkenes, the predominant were aristolen, cyclohexene, 3-ethenyl-4-(1-methylethenyl), and à-muurolene-(-), with relative contents of $2.29 \%$, $1.16 \%$ and $1.04 \%$.

Nine esters and ten alkenes were identified in the T2 fruit, with total relative contents of $88.01 \%$ and $11.98 \%$, respectively. The relative content of hexanoic acid, ethyl ester, $26.11 \%$, was the highest of the nine esters. This was followed by hexanoic acid, methyl ester and octanoic acid, methyl ester, with relative contents of $25.71 \%$ and $15.43 \%$, respectively. Three alkenes, à-copaene, aristolen and à-muurolene-(-), were the predominant alkenes, with the highest relative contents of $2.71 \%, 2.68 \%$ and $2.21 \%$, respectively.
There were also 19 types of aroma components identified in T0, comprising ten esters and nine alkenes. For the ten esters, the relative content of hexanoic acid, methyl ester, $62.61 \%$, was the highest and was followed by octanoic acid, methyl ester and propanoic acid, 3-(methylthio)- methyl ester, with relative contents of $15.08 \%$ and $4.36 \%$, respectively. For the nine alkenes, the predominant were aristolen, cyclohexene, 3-ethenyl-4-(1-methylethenyl), and 1,3,6-octatriene, 3,7-dimethyl-, (E) with relative content of $2.87 \%$, $1.74 \%$ and $1.07 \%$, respectively.

In general, the assessment of the aroma components showed that there were more types of esters, with higher total relative contents, in the $\mathrm{T} 1$ fruits and more types of alkenes, with higher total relative contents, in the T2 fruits (Table 3). Similar findings were reported by Wang et al. (2005) for apple fruits.

Only a few types of aroma components with low aroma thresholds values were defined as the characteristic aroma components contributing greatly to the fragrance of the fruits. The sulfur-containing esters, propanoic acid, 3-(methylthio)- methyl ester and 3-(methylthio) propanoic acid ethyl ester, were the characteristic aroma components of pineapple fruits (Engel et al., 1990; Preston et al., 2003). Similar to a previous study (Liu et al. 2011a), only one characteristic ester, propanoic acid, 3-(methylthio) -methyl ester, was identified in the present study. The relative contents of propanoic acid, 3-(methylthio) -methyl ester for T1 (5.79\%) and T2 (5.59\%) were both increased compared with T0 (4.36\%). This result was similar to a previous work by Wang et al. (2005) that stated that the 2-methyl-, (S)-, 1-hexanol contributing to the characteristic aroma of 'Fuji' apples was only detected in organically grown fruits.

The application of organic manure has a positive effect on the chemical quality and fragrance of fruits (Pérez-López et al., 2007), which is due adequate amounts and a balanced ratio of nutrients in the organ- 
ic fertilizers being available when needed by the plant (Heeb et al., 2006); organic manure increases the soil fertility and supports a preferable condition for plant growth (Thybo et al., 2006; Li et al., 2009, Chang et al., 2010). In our previous study, it was found that peanut-press pulp application improved the soil fertility and promoted the growth of pineapple plants (Liu et al., 2009b). The application of peanut-press pulp also improved the activities of urease, invertase, cata- lase and prolease of soil and the population of microorganisms in the pineapple orchard soil. Furthermore, peanut-press pulp application increased certain physiological indices of pineapple plants, such as the content of soluble sugar and protein, activity of SOD in the leaves and roots and root activity. Perhaps, that is the reason why peanut-press pulp addition improved the chemical quality and fragrance of the pineapple fruits ripened in winter in this study.

Table 2. Aroma components and relative contents in pineapple fruits of the treatment and control

\begin{tabular}{|c|c|c|c|c|c|}
\hline \multirow{2}{*}{ Categories } & \multirow{2}{*}{ Component name } & \multirow{2}{*}{$\begin{array}{c}\text { Molecular } \\
\text { formula }\end{array}$} & \multicolumn{3}{|c|}{ Relative contents $(\%)$} \\
\hline & & & T1 & $\mathbf{T 2}$ & T0 \\
\hline \multirow{17}{*}{ Esters } & Hexanoic acid, methyl ester & $\mathrm{C}_{7} \mathrm{H}_{14} \mathrm{O}_{2}$ & 55.14 & 25.71 & 62.61 \\
\hline & Hexanoic acid, ethyl ester & $\mathrm{C}_{8} \mathrm{H}_{16} \mathrm{O}_{2}$ & - & 26.11 & 2.20 \\
\hline & $\begin{array}{l}\text { Propanoic acid, 3-(methylthio)-, } \\
\text { methyl ester }\end{array}$ & $\mathrm{C}_{5} \mathrm{H}_{10} \mathrm{O}_{2} \mathrm{~S}$ & 5.79 & 5.59 & 4.36 \\
\hline & Heptanoic acid, methyl ester & $\mathrm{C}_{8} \mathrm{H}_{16} \mathrm{O}_{2}$ & - & - & 1.42 \\
\hline & Hexanoic acid, 5-methyl-, methyl ester & $\mathrm{C}_{8} \mathrm{H}_{16} \mathrm{O}_{2}$ & 0.86 & - & - \\
\hline & Pentanoic acid, 2-methyl-, methyl ester & $\mathrm{C}_{7} \mathrm{H}_{14} \mathrm{O}_{2}$ & 0.30 & - & - \\
\hline & 4-octenoic acid, methyl ester, (Z) & $\mathrm{C}_{9} \mathrm{H}_{16} \mathrm{O}_{2}$ & 1.42 & 1.27 & 1.60 \\
\hline & Octanoic acid, methyl ester & $\mathrm{C}_{9} \mathrm{H}_{18} \mathrm{O}_{2}$ & 25.85 & 15.43 & 15.08 \\
\hline & Octanoic acid, ethyl ester & $\mathrm{C}_{10} \mathrm{H}_{20} \mathrm{O}_{2}$ & - & - & 0.69 \\
\hline & Hexanoic acid, 5-(acetyloxy)-, methyl ester & $\mathrm{C}_{9} \mathrm{H}_{16} \mathrm{O}_{4}$ & 0.61 & 0.49 & 0.48 \\
\hline & Decanoic acid, methyl ester & $\mathrm{C}_{11} \mathrm{H}_{22} \mathrm{O}_{2}$ & 0.45 & - & - \\
\hline & Ethyl 3-acetoxy hexanoate & $\mathrm{C}_{10} \mathrm{H}_{18} \mathrm{O}_{4}$ & - & 0.82 & - \\
\hline & Methyl decadienoate & $\mathrm{C}_{11} \mathrm{H}_{18} \mathrm{O}_{2}$ & - & 0.69 & 0.68 \\
\hline & Pentane-1,1-diol diethanoate & $\mathrm{C}_{9} \mathrm{H}_{16} \mathrm{O}_{4}$ & 0.29 & - & - \\
\hline & Methyl 4-acetylhydroxypalmitate & $\mathrm{C}_{19} \mathrm{H}_{36} \mathrm{O}_{4}$ & 0.32 & - & - \\
\hline & Methyl 5-acetylhydroxypalmitate & $\mathrm{C}_{19} \mathrm{H}_{36} \mathrm{O}_{4}$ & 0.23 & - & - \\
\hline & Methyl 3-acetoxyhexanoate & $\mathrm{C}_{9} \mathrm{H}_{16} \mathrm{O}_{4}$ & 3.19 & 11.90 & 2.19 \\
\hline Alcohol & Farnesol & $\mathrm{C}_{15} \mathrm{H}_{26} \mathrm{O}$ & 0.09 & - & - \\
\hline
\end{tabular}


Continued...

\begin{tabular}{|c|c|c|c|c|c|}
\hline \multirow{2}{*}{ Categories } & \multirow{2}{*}{ Component name } & \multirow{2}{*}{$\begin{array}{l}\text { Molecular } \\
\text { formula }\end{array}$} & \multicolumn{3}{|c|}{ Relative contents (\%) } \\
\hline & & & T1 & T2 & T0 \\
\hline \multirow{13}{*}{ Alkenes } & $\begin{array}{l}\text { Cyclohexene, 3-ethenyl-4-(1-methylethen- } \\
\text { yl) }\end{array}$ & $\mathrm{C}_{11} \mathrm{H}_{16}$ & 1.16 & 1.25 & 1.74 \\
\hline & 1,3,6-octatriene, 3,7-dimethyl-, (E) & $\mathrm{C}_{10} \mathrm{H}_{16}$ & - & - & 1.07 \\
\hline & Aristolen & $\mathrm{C}_{15} \mathrm{H}_{24}$ & 2.29 & 2.68 & 2.87 \\
\hline & à-gurjunene & $\mathrm{C}_{15} \mathrm{H}_{24}$ & - & 0.35 & 0.37 \\
\hline & Sativen, $(+)$ & $\mathrm{C}_{15} \mathrm{H}_{24}$ & 0.29 & 0.31 & 0.52 \\
\hline & à-copaene & $\mathrm{C}_{15} \mathrm{H}_{24}$ & - & 2.71 & - \\
\hline & á elemene & $\mathrm{C}_{15} \mathrm{H}_{24}$ & - & 0.55 & 0.43 \\
\hline & Germacrene-D & $\mathrm{C}_{15} \mathrm{H}_{24}$ & - & 0.63 & - \\
\hline & (-)-Isoledene & $\mathrm{C}_{15} \mathrm{H}_{24}$ & - & 0.31 & - \\
\hline & Valencene & $\mathrm{C}_{15} \mathrm{H}_{24}$ & - & 0.98 & - \\
\hline & Calarene & $\mathrm{C}_{15} \mathrm{H}_{24}$ & 0.48 & - & 0.53 \\
\hline & à-muurolene-(-) & $\mathrm{C}_{15} \mathrm{H}_{2}$ & 1.04 & 2.21 & 0.98 \\
\hline & Delta.-cadinene & $\mathrm{C}_{15} \mathrm{H}_{4}$ & 0.19 & - & 0.17 \\
\hline
\end{tabular}

Note: - not found

Table 3. Aromatic categories and relative contents in pineapple fruits of treatments and control

\begin{tabular}{lcccccc}
\hline \multirow{2}{*}{ Categories } & \multicolumn{3}{c}{ Relative content (\%) } & \multicolumn{3}{c}{ Number } \\
\cline { 2 - 7 } & T1 & T2 & T0 & T1 & T2 & T0 \\
\hline Esters & 94.45 & 88.01 & 91.31 & 12 & 9 & 10 \\
Alcohol & 0.09 & - & - & 1 & - & - \\
Alkenes & 5.45 & 11.98 & 8.68 & 6 & 10 & 9 \\
Total & 99.99 & 99.99 & 99.99 & 19 & 19 & 19 \\
\hline
\end{tabular}

Note: - not found

\section{Conclusion}

According to the overall results, it was concluded that the growth and quality of pineapple fruits ripened in winter were promoted by the addition of organic fertilizer; the treatment accelerated the ripening of the pineapple fruits by $2 \sim 7$ days and enhanced the weight per fruit. The quality of pineapple fruits ripened in winter was improved with regard to parameters, including the TSS and total sugar. The sensory evalua- tion also indicated that the pineapple fruits under the organic manure addition treatments were sweeter in smell and better in fragrance. There were more types of ester aroma components, with higher total relative contents, in the $\mathrm{T} 1$ fruits, and there were more types of alkene aroma components, with higher total relative contents, in the $\mathrm{T} 2$ fruits. The relative contents of the characteristic aroma components of pineapple fruits were increased by the two organic manure addition treatments when compared with the control. 


\section{Acknowledgements}

This work was financially supported by Sci-tech Project (2010B031800012) from Guangdong Province of P. R. China and Special Fund for Agro-scientific Research in the Public Interest (201203021) from Ministry of Agriculture of P. R. China.

\section{References}

Abou El- Magd, M. M., El-Bassiony, A. M., Fawzy, Z. F. 2006. Effect of organic manure with or without chemical fertilizers on growth, yield and quality of some varieties of broccoli plants. Journal of Applied Sciences Research. 2, 791-798.

Bourn, D., Prescott, J. 2002. A comparison of the nutritional value, sensory qualities, and food safety of organically and conventionally produced foods. Critical Reviews in Food Science and Nutrition. 42, 1-34.

Chang, E. H., Chung, R. S., Tsai, Y. H. 2007. Effect of different application rates of organic fertilizer on soil enzyme activity and microbial population. Soil Science and Plant Nutrition. 53,132-140.

Chang, K. H., Wu, R. Y., Chuang, K. C., Hsieh, T. F., Chung, R. S. 2010. Effects of chemical and organic fertilizers on the growth, flower quality and nutrient uptake of Anthurium andreanum, cultivated for cut flower production. Scientia Horticulturae. $125,434-441$.

Ekelund, L., Tjärnemo, H. 2004. Consumer preferences for organic vegetables - the case of Sweden. Acta Horticulture. 655, 121-128.

Elss, S., Preston, C., Hertzig, C., Heckel, F., Richling, E., Schreier, P. 2005. Aroma profiles of pineapple fruit (Ananas comosus[L].Merr.) and pineapple products. LWT-Food Science and Technology. 38, 263-274.
Engel, K. H., Heidlas, J., Tressl, R. 1990. The flavor of tropical fruits (banana, melon, pineapple). In I. D. Morton, and A. J. MacLeod (Eds.), developments in food science 3C (food flavours). Elsevier, Amsterdam, pp. 195-219.

Heeb, A., Lundegårdh, B., Savage, G., Ericsson, T. 2006. Impact of organic and inorganic fertilizers on yield, taste, and nutritional quality of tomatoes. Journal of Plant Nutrition and Soil Science. 169, 535-541.

Lai, T., Shen, Q. R., Chu, B. Q., Zhang, C. L. 2005. Effects of organic manure on soil $\mathrm{N}$ supplying and strawberry quality. Chinese Journal of Soil Science. 36, 891-895.

Li, J. J., Zou, G. Y., Song, D. T., Xu, Z. T., Sun, Q. P., Liu, B. S. 2009. Influence of compost and chemical fertilizers on tomato yield and quality. Chinese Journal of Soil Science. 40, 1330-1332.

Liu, C. H., Liu, Y., Yi, G. J., Li, W. L., Zhang, G. P. 2011a. A comparison of aroma components of pineapple fruits ripened in different seasons. African Journal of Agricultural Research. 6, 17711778.

Liu, C. H., Liu, Y., Yi, G. J., Liao, M. J., Wei, F. L., Zhu, S. Q. 2009b. Physiological and biochemical mechanisms of different organic fertilizer applications affecting pineapple plant growth. Acta Botanica Boreali-occidentalia Sinica. 29, 25272534

Liu, C. H., Liu, Y., Yi, G. J., Liao, M. J., Wu, Y. Z., Wei, F. L., Zhu, S. Q. 2011b. Effects of film mulching on aroma components of pineapple fruits. Journal of Agricultural Science. 3(3), 196-201.

Lu K. G., Zhu, S. H., Zhang, L. Z. 2003. The effect of biofertilizer on soil property and fruit quality of red Fuji apple. Journal of Shihezi University (Natural Science Edition). 7(3), 205-208. 
Marzouka, H. A., Kassem, H. A. 2011. Improving fruit quality, nutritional value and yield of $\mathrm{Za}-$ ghloul dates by the application of organic and / or mineral fertilizers. Scientia Horticulturae. 127, 249-254.

Pérez-López, A. J., López-Nicolás, J. M., CarbonellBarrachina, A. A. 2007. Effects of organic farming on minerals contents and aroma composition of Clemenules mandarin juice. European Food Research and Technology. 225, 255-260.

Preston, C., Richling, E., Elss, S., Appel, M., Heckel, F., Hartlieba, A., Schreier, P. 2003. On-line gas chromatography combustion/pyrolysis isotope ratio mass spectrometry (HRGC-C/P-IRMS) of pineapple (Ananas comosus L.Merr.) volatiles. Journal of Agriculture and Food Chemistry. 51, 8027-8031.

Shao, H., Huang, Y. D. 2010. Effect of fermented bio-organic fertilizer on growth and fruit quality of organic tomato. Guizhou Agricultural Science. 38(5), 63-65.

Shi, C. Y., Zhang, F. D., Zhang, S. Q., Li, H., Fu, C. G. 2004. Effects of organic-inorganic compound fertilizers on yield quality and some related physiological characteristics in tomato. Scientia Agricultura Sinica. 37, 1183-1187.

Shimbo, S., Zhang, Z. W., Watanabe, T., Nakatsuka, H., Matsuda-Inoguch, N., Higashikawa, K., Ikeda, M. 2001. Cadmium and lead contents in rice and other cereal products in Japan in 1998-2000. Science of the Total Environment. 281, 165-175.

Tang, X. N., Pan, C. Y., Zhang, J. H. 2008. Research of the eco-organic fertilizer and potash fertilizer on grape quality. Journal of Shandong Agricultural University (Natural Science). 39,570-571.

Tejada, M., Gonzalez, J. L. 2003. Effects of the application of a compost originating from crushed cotton gin residues on wheat yield under dryland conditions. European Journal of Agronomy. 19, 357-368.

Thybo, A. K., Edelenbos, M., Christensen, L. P., Sørensen, J. N., Thorup-Kristensen, K. 2006. Effect of organic growing systems on sensory quality and chemical composition of tomatoes. LWTFood Science and Technology. 39, 835-843.

Wang, X. D., Shi. D. C., Song. Y., Zhai, H. 2005. GC-M S analysis of fruit aroma components of organic 'fuji' apple. Acta Horticulturae Sinica. 32, 998-1002.

Ye, J. X., Wu, C. Y., Shen, L. L., Zhang, X. M., Zhang, G. C., Song, S. Y. 2004. Effect of combined application of organic manure and fertilizer on Chinese cabbage yield and quality. Journal of Jilin Agricultural University. 26(2), 155-157, 161.

Zaccone, C., Caterina, R. D., Rotunno, T., Quinto, M. 2010. Soil-farming system-food-health: Effect of conventional and organic fertilizers on heavy metal $(\mathrm{Cd}, \mathrm{Cr}, \mathrm{Cu}, \mathrm{Ni}, \mathrm{Pb}, \mathrm{Zn})$ content in semolina samples. Soil \& Tillage Research. 107, 97-105. 